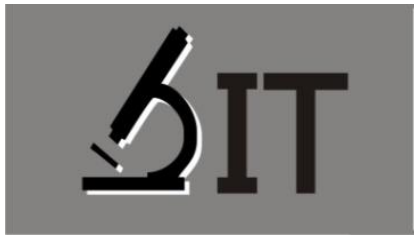

p-ISSN : $2597-8977$

e-ISSN : 2597-8985

Nurmawaddah*)

Universitas Negeri Makassar

Ramlawati

Universitas Negeri Makassar

Muhammad Aqil Rusli Universitas Negeri Makassar

*) Correspondence Author: wahda.nurmawaddah@gmail.com

\section{DESKRIPSI MISKONSEPSI PESERTA DIDIK PADA MATA PELAJARAN IPA DENGAN MENGGUNAKAN TES DIAGNOSTIK TWO - TIER MUL TIPLE CHOICE QUESTION DI KELAS VIII}

Abstrak: Penelitian ini bertujuan untuk mengetahui deskripsi tingkat miskonsepsi peserta didik di kelas VIII SMPN 3 Makassar. Penelitian ini merupakan penelitian deskriptif kuantitatif. Populasi penelitian adalah seluruh peserta didik kelas VIII SMP Negeri 3 Makassar yang berjumlah 393 orang sekaligus sebagai sampel penelitian. Instrumen penelitian yang digunakan berupa tes diagnostik two-tier multiple choice question berbentuk pilihan ganda beralasan yang disertai dengan CRI (Certainty Response Index) yang berjumlah 20 item. Teknik pengumpulan data dalam penelitian ini adalah pemberian tes diagnostik two - tier multiple choice question. Teknik analisis data dilakukan dengan berpedoman pada jawaban peserta didik yang diberikan pada tingkat pertama, tingkat kedua dan tingkat keyakinan sehingga dapat diketahui jumlah peserta didik yang paham konsep, miskonsepsi, serta tidak paham konsep. Hasil analisis data menunjukkan bahwa miskonsepsi peserta didik yang teridentifikasi terjadi di setiap konsep pada materi gerak pada benda. Tingkat miskonsepsi peserta didik pada konsep gerak lurus memiliki persentase sebesar 57,5\% dan untuk konsep gaya persentase miskonsepsi peserta didik sebesar 41,7\%. Sedangkan untuk konsep Hukum Newton memiliki persentase miskonsepsi sebesar $49,6 \%$.

Kata Kunci: Gerak lurus, Miskonsepsi, Two - Tier Multiple Choice Question.

Abstract: The purpose of this study is to describe students' level of misconception in class VIII of SMPN 3 Makassar. This research is quantitative descriptive. There are 393 students of class VIII as the population as well as the sample of this study. Instrument of this study is a two-tier multiple choice question diagnostic test in the form of a reasonable multiple choice accompanied by a CRI (Certainty Response Index). There are 20 item items that had been validated by experts and tested at SMPN 1 Makassar. The data collection technique is giving a twotier multiple choice question diagnostic test. The data analysis technique was carried out by referring to the students' answers given at the first level, the second level and the level of certainty so it could be seen the number of students who understood the concept, misconceptions, and did not understand the concept. The results show that the students' misconceptions that were identified in each concept of "Motion". The level of students' 'misconceptions in "linear motion" is $57.5 \%$, for the concept of "force" the percentage of students' misconceptions is $41.7 \%$. Whereas the concept of Newton's Law has a percentage of misconceptions that is $49.6 \%$.

Keyword: Linear motion, Misconception, Two-Tier Multiple Choice 


\section{PENDAHULUAN}

Ilmu Pengetahuan Alam merupakan ilmu pengetahuan yang mempelajari serangkaian gejala ilmiah alam yang telah diuji kebenarannya melalui proses ilmiah. Ilmu pengetahuan alam meliputi pengetahuan ilmiah baik berupa konsep, fakta-fakta dan prinsip-prinsip yang berhubungan dengan alam sekitarnya. Oleh karena itu, pembelajaran IPA diharapkan dapat mencapai tujuan agar peserta didik dapat memahami konsep, aplikasi konsep dan mampu mengaitkan satu konsep dengan konsep yang lainnya karena hal ini merupakan landasan mereka untuk berpikir (Wisudawati, 2014).

Paham konsep bagi peserta didik dapat diartikan sebagai pemahaman peserta didik tentang konsep yang telah didapat dalam pembelajaran yang tersimpan dalam pikiran mereka yang nantinya dapat diaplikasikan dalam kehidupan sehari-hari. Pemahaman konsep peserta didik saat ini hanya berorientasi pada pemahaman mereka yang dikembangkan berdasarkan apa yang mereka lihat dan dengar untuk memahami suatu konsep yang mereka pelajari.

Sebelum memasuki jenjang pendidikan sekolah, peserta didik sudah memiliki konsep pengetahuan awal yang diperoleh dari pengalaman dan informasi berbeda-beda yang kurang akurat. Hal ini yang dapat menyebabkan pengetahuan yang dimiliki peserta didik dapat benar ataupun salah. Pengetahuan awal yang dimiliki peserta didik ini memiliki peranan besar dalam proses pembelajaran mereka kerena jika kesalahan konsep di awal akan sangat mempengaruhi pemahaman konsep pada materi selanjutnya yang saling berkaitan. Menurut Suparno (2005), miskonsepsi atau salah konsep merupakan konsep yang tidak sesuai dengan pengertian ilmiah atau pengertian yang diterima para ilmuwan pada bidang yang bersangkutan. Miskonsepsi adalah kepercayaan yang tidak sesuai dengan penjelasan yang diterima umum dan terbukti tidak sahih tentang suatu fenomena atau peristiwa yang terjadi (Ormrod, 2009).

Berdasarkan penelitian yang dilakukan oleh Siswana (2017) tentang miskonsepsi pada peserta didik yang menyebutkan bahwa yang menjadi penyebab miskonsepsi pada peserta didik yaitu dari faktor diri peserta didik itu sendiri dan buku teks yang digunakan serta kesulitan peserta didik dalam memahami konsep. Menurut Odom, buku pelajaran juga dapat menyebabkan miskonsepsi bagi peserta didik, hal ini karena bahasa yang digunakan oleh pengarang buku untuk memaparkan suatu konsep mungkin dianggap berbeda oleh peserta didik (Mustaqim, 2014).

Para ahli di bidang miskonsepsi menemukan beberapa penyebab miskonsepsi pada peserta didik di antaranya adalah berasal dari peserta didik itu sendiri, guru, buku teks dan metode pembelajaran yang digunakan oleh peserta didik dalam proses pembelajaran. Peserta didik yang mengalami miskonsepsi juga dapat dikarenakan oleh adanya kesulitan peserta didik dalam memahami konsep. Bentuk miskonsepsi dapat berupa kesalahan konsep, hubungan yang tidak benar antar konsep, dan gagasan intuitif atau pandangan yang naif (Suparno, 2005).

Berdasarkan observasi yang telah dilakukan di SMPN 3 Makassar dengan wawancara dengan guru mata pelajaran IPA, materi IPA yang berpotensi miskonsepsi pada peserta didik khususnya kelas VIII adalah materi biologi dan fisika. Karakteristik materi ini yang bersifat abstrak sehingga sulit bagi peserta didik untuk paham tentang materi tersebut. Hal ini sesuai dengan penelitian yang telah dilakukan oleh Siswana (2017) menyebutkan bahwa kesulitan belajar peserta didik disebabkan oleh materi yang bersifat abstrak yang tidak bisa diamati peserta didik secara nyata sehingga berpeluang menyebabkan miskonsepsi.

Selain itu miskonsepsi juga berpotensi disebabkan oleh guru mata pelajaran yang tidak menguasai materi yang akan diajarkan karena bukan bidang keahliannya. Guru yang tidak menguasai bahan pembelajaran secara benar akan menyebabkan peserta didik mendapatkan miskonsepsi (Suparno, 2005). Hal inilah yang menjadikan guru merupakan salah satu faktor yang memiliki andil terhadap pembentukan miskonsepsi pada peserta didik di SMPN 3 Makassar.

Miskonsepsi yang terjadi pada peserta didik harus terlebih dahulu diidentifikasi sebelum diperbaiki. Identifikasi bertujuan untuk membedakan peserta didik yang paham konsep, miskonsepsi dan tidak paham konsep. Pemilihan metode yang tepat untuk mengidentifikasi 
miskonsepsi sangat penting. Salah satu cara yang dapat dilakukan untuk mengetahui miskonsepsi sekaligus membedakan peserta didik yang paham konsep dan tidak paham konsep yaitu dengan pemberian tes diagnostik.

Tes diagnostik yang tepat yang dapat digunakan untuk mengetahui tingkat miskonsepsi yang terjadi pada peserta didik yaitu tes diagnostik two-tier multiple choice question. Two-tier multiple choice question merupakan instrumen tes yang terdiri dari dua tingkat, tingkat pertama terdiri atas pertanyaan dan tingkat kedua terdiri atas pilhan alasan yang mengacu pada jawaban pada tingkat pertama (Tuysuz, 2009). Tes ini sengat efektif digunakan untuk mengetahui tingkat miskonsepsi yang terjadi pada peserta didik karena dapat menganalisa jawaban peserta didik sehingga dapat dibedakan peserta didik yang paham konsep, tidak paham konsep dan miskonsepsi. Penggunaan tes diagnostic ini disertai dengan Certainty of Response Index (CRI) yang merupakan metode yang digunakan untuk mengukur tingkat keyakinan/kepastian responden dalam menjawab setiap soal/pertanyaan yang diberikan (Hasan, 1999).

Menurut Arslan, Cigdemoglu, \& Moseley (2012) interpretasi respon yang diberikan oleh responden terhadap tes diagnostik two tier multiple choice question digambarkan dalam Tabel 1.

Tabel 1. Kemungkinan Respons Two Tier Test

\begin{tabular}{cccc}
\hline Jawaban & Alasan & CRI & Kategori \\
\hline Benar & Benar & $>2,5$ (Yakin) & Paham Konsep \\
Benar & Salah & $>2,5$ (Yakin) & Miskonsepsi \\
Salah & Benar & $>2,5$ (Yakin) & Miskonsepsi \\
Salah & Salah & $>2,5$ (Yakin) & Miskonsepsi \\
Benar & Benar & $<2,5$ (Tidak Yakin) & Kurang Paham Konsep \\
Benar & Salah & $<2,5$ (Tidak Yakin) & Tidak Paham konsep \\
Salah & Benar & $<2,5$ (Tidak Yakin) & Tidak Paham konsep \\
Salah & Salah & $<2,5$ (Tidak Yakin) & Tidak Paham konsep \\
\hline
\end{tabular}

Berdasarkan Tabel 1. dapat dilihat bahwa miskonsepsi yang terjadi pada peserta didik dapat diidentifikasi dengan ketentuan bahwa (1) apabila peserta didik menjawab benar pada tingkat satu (pilihan jawaban) dan salah pada tingkat dua (alasan jawaban) dengan skala CRI > 2,5; (2) apabila peserta didik menjawab salah pada tingkat satu (pilihan jawaban) dan benar pada tingkat dua (alasan jawaban) dengan skala CRI > 2,5 ; (3) apabila peserta didik menjawab salah pada tingkat satu (pilihan jawaban) dan salah pada tingkat dua (alasan jawaban) dengan skala CRI >2,5.

Penelitian yang telah dilakukan oleh Wiyono, Sugiyanto, \& Erni, (2016) tentang Identifikasi Hasil Analisis Miskonsepsi Gerak Menggunakan Instrumen Diagnostik Three Tier pada Siswa SMP diperoleh bahwa miskonsepsi yang terjadi pada peserta didik pada materi gerak yaitu suatu benda dikatakan bergerak ketika posisinya berubah tanpa pemberitahuan titik referensi, kecepatan adalah jarak tempuh benda dibagi waktu tempuh dan memiliki arah, kecepatan merupakan jarak tempuh benda dibagi waktu dan tidak memiliki arah, benda yang awalnya bergerak dengan kecepatan konstan, dan tiba-tiba berhenti maka ia akan terus bergerak tidak searah laju awal gerak benda dalam menjaga kondisinya seperti semula dan hal-hal yang awalnya diam, dan diberikan gerakan sangat cepat maka hal-hal akan terjadi.

Berdasarkan hasil observasi, wawancara dan beberapa penelitian yang telah dikemukakan maka peneliti akan melakukan penelitian tentang miskonsepsi pada peserta didik agar menjadi acuan bagi pendidik dan calon pendidik untuk mengetahui tingkat pemahaman peserta didik terhadap konsep IPA di SMPN 3 Makassar dengan judul penelitian "Deskripsi Miskonsepsi Peserta Didik Pada Mata Pelajaran IPA dengan Menggunakan Tes Diagnostik Two - Tier Multiple Choice Question di Kelas VIII SMPN 3 Makassar. Penelitian ini bertujuan untuk untuk mengetahui deskripsi 
tingkat miskonsepsi peserta didik pada mata pelajaran IPA kelas VIII di SMPN 3 Makassar studi pada materi gerak benda.

\section{METODE}

Jenis penelitian yang dilakukan adalah penelitian deskriptif kuantitatif dengan menuturkan dan menafsirkan data yang berkenaan dengan fakta, keadaaan, variabel dan fenomena yang terjadi pada saat penelitian berlangsung dan menyajikan apa adanya. Penelitian deskriptif bertujuan untuk memperoleh gambaran permasalahan yang dihadapi dengan melihat besaran dan ciri-ciri dari berbagai variabel kunci yang dianggap dapat memberikan gambaran yang utuh. Penelitian ini dilakukan untuk mendapatkan gambaran tingkat miskonsepsi yang terjadi pada peserta didik, sehingga dapa dibedakan antara peserta didik yang paham konsep, tidak tahu konsep dan miskonsepsi.

Penelitian ini dilakukan pada semester ganjil tahun pelajaran 2019/2020. Dalam penelitian ini wilayah atau tempat penelitian yang menjadi pusat penelitian berlokasi di SMPN 3 Makassar. Populasi dalam penelitian ini adalah seluruh peserta didik kelas VIII di SMPN 3 Makassar Tahun Pelajaran 2019/2020 yang terdiri dari 12 kelas dengan jumlah peserta didik sebanyak 393 orang. Teknik yang digunakan adalah sampling jenuh yaitu teknik penentuan sampel bila semua anggota populasi digunakan sebagai sampel.

Data diperoleh dengan memberikan tes pilihan ganda beralasan (two tier multiple choice question) yang pada sampel penelitian. Setelah diberikan tes, hasil tes tersebut dikelompokkan berdasarkan kategori tingkatan pemahaman konsep peserta didik yaitu paham konsep, tidak paham konsep dan miskonsepsi. Untuk memperoleh kategori pemahaman peserta didik maka jawaban peserta didik yang diperoleh dianalisis dengan pedoman penskoran di mana skor yang diberikan jika peserta didik menjawab pilihan ganda dengan benar adalah 1, jika menjawab salah skornya o. Untuk Jawaban alasan benar diberi sedangkan untuk kriteria jawaban peserta didik yang dikatakan miskonsepsi ada dua yaitu, pertama jika jawaban yang dipilih benar, alasan salah dan tingkat keyakinan memilih jawaban $>2,5$. Kedua jika jawaban salah, alasan salah serta tingkat keyakinan > 2,5 maka peserta didik mengalami miskonsepsi. Instrumen yang digunakan dalam penelitian berupa instrumen tes pilihan ganda beralasan (two tier multiple choice) untuk mengetahui ada tidaknya miskonsepsi yang terjadi pada peserta didik.

\section{HASIL DAN PEMBAHASAN}

\section{Hasil}

Penelitian yang telah dilakukan yaitu untuk mendeskripsikan miskonsepsi peserta didik pada materi gerak benda dengan menggunakan tes diagnostic two-tier multiple choice question. Jumlah soal yang diujikan sebanyak 20 butir soal yang mencakup 3 konsep yaitu gerak lurus, gaya dan Hukum Newton. Setelah dilakukan penelitian dan analisis data diperoleh data kategori pemahaman peserta didik yang dapat dilihat dari Tabel 2.

Tabel 2. Kategori Pemahaman Konsep Peserta Didik

\begin{tabular}{|c|c|c|c|c|c|c|c|c|c|c|}
\hline \multirow{2}{*}{ Konsep } & \multirow{2}{*}{ Indikator soal } & \multirow{2}{*}{$\begin{array}{c}\text { No } \\
\text { Soal }\end{array}$} & \multicolumn{2}{|c|}{ PB } & \multicolumn{2}{|c|}{ PK } & \multicolumn{2}{|c|}{ TP } & \multicolumn{2}{|c|}{$M$} \\
\hline & & & Frek. & $\%$ & Frek. & $\%$ & Frek. & $\%$ & Frek. & $\%$ \\
\hline \multirow[t]{4}{*}{ Gerak Lurus } & Menafsirkan & 1 & 157 & 39.9 & 13 & 3.3 & 38 & 9.7 & 185 & 47.1 \\
\hline & & $\overline{\boldsymbol{x}}$ & 157 & 39.9 & 13 & $3 \cdot 3$ & 38 & 9.7 & 185 & 47.1 \\
\hline & Membandingkan & 2 & 148 & 37.7 & 5 & 1.3 & 34 & 8.7 & 206 & 52.4 \\
\hline & & 3 & 130 & 33.1 & 4 & 1.0 & 58 & 14.8 & 201 & 51.1 \\
\hline
\end{tabular}




\begin{tabular}{|c|c|c|c|c|c|c|c|c|c|c|}
\hline \multirow{2}{*}{ Konsep } & \multirow{2}{*}{ Indikator soal } & \multirow{2}{*}{$\begin{array}{l}\text { No } \\
\text { Soal }\end{array}$} & \multicolumn{2}{|c|}{ PB } & \multicolumn{2}{|c|}{ PK } & \multicolumn{2}{|c|}{ TP } & \multicolumn{2}{|c|}{ M } \\
\hline & & & Frek. & $\%$ & Frek. & $\%$ & Frek. & $\%$ & Frek. & $\%$ \\
\hline & & 4 & 96 & 24.4 & 4 & 1.0 & 67 & 17.0 & 226 & 57.5 \\
\hline & & $\bar{x}$ & 125 & 31.7 & 4 & 1.1 & 53 & 13.5 & 211 & 53.6 \\
\hline & Mencontohkan & 5 & 148 & 37.7 & 8 & 2.0 & 58 & 14.8 & 179 & 45.5 \\
\hline & & 6 & 157 & 39.9 & 8 & 2.0 & 53 & 13.5 & 175 & $44 \cdot 5$ \\
\hline & & 7 & 129 & 32.8 & 16 & 4.1 & 85 & 21.6 & 163 & 41.5 \\
\hline & & $\bar{x}$ & 145 & 36.8 & 11 & 2.7 & 65 & 16.6 & 172 & 43.8 \\
\hline & Mengklasifikasikan & 8 & 148 & 37.7 & 8 & 2.0 & 81 & 20.6 & 156 & 39.7 \\
\hline & & 9 & 121 & 30.8 & 12 & 3.1 & 105 & 26.7 & 155 & 39.4 \\
\hline & & $\bar{x}$ & 135 & 34.2 & 10 & 2.5 & 93 & 15.7 & 155 & 39.5 \\
\hline \multirow{4}{*}{ Gaya } & \multirow{2}{*}{ Menafsirkan } & 10 & 119 & 30.3 & 25 & 6.4 & 85 & 21.6 & 164 & 41.7 \\
\hline & & $\bar{x}$ & 119 & 30.3 & 25 & 6.4 & 85 & 21.6 & 164 & 41.7 \\
\hline & \multirow{2}{*}{ Menafsirkan } & 11 & 111 & 28.2 & 13 & $3 \cdot 3$ & 106 & 27.0 & 163 & 41.5 \\
\hline & & $\bar{x}$ & 111 & 28.2 & 13 & $3 \cdot 3$ & 106 & 27.0 & 163 & 41.5 \\
\hline \multirow{11}{*}{$\begin{array}{l}\text { Hukum } \\
\text { Newton }\end{array}$} & \multirow[t]{6}{*}{ Mencontohkan } & 12 & 75 & 19.1 & 11 & 2.8 & 112 & 28.5 & 195 & 49.6 \\
\hline & & 13 & 121 & 30.8 & 8 & 2.0 & 128 & 32.6 & 136 & 34.6 \\
\hline & & 14 & 112 & 28.5 & 17 & $4 \cdot 3$ & 124 & 31.6 & 140 & 35.6 \\
\hline & & 15 & 129 & 32.8 & 22 & 5.6 & 109 & 27.7 & 133 & 33.8 \\
\hline & & 16 & 133 & 33.8 & 23 & $5 \cdot 9$ & 84 & 21.4 & 153 & 38.9 \\
\hline & & $\bar{x}$ & 114 & 29 & 16 & 15.8 & 111 & 28.3 & 151 & 38.5 \\
\hline & \multirow[t]{5}{*}{ Mengategorikan } & 17 & 115 & $29 \cdot 3$ & 25 & 6.4 & 105 & 26.7 & 148 & 37.7 \\
\hline & & 18 & 112 & 28.5 & 30 & 7.6 & 100 & 25.4 & 151 & 38.4 \\
\hline & & 19 & 130 & 33.1 & 26 & 6.6 & 65 & 16.5 & 172 & 43.8 \\
\hline & & 20 & 123 & 31.3 & 28 & 7.1 & 61 & $15 \cdot 5$ & 181 & 46.1 \\
\hline & & $\bar{x}$ & 120 & 30.5 & 26 & 6.9 & 83 & 21 & 163 & 41.5 \\
\hline
\end{tabular}

Keterangan:

PB = Paham Konsep dengan Baik

$\mathrm{PK}=$ Kurang Paham Konsep

TP = Tidak Paham Konsep

$\mathrm{M}=$ Miskonsepsi

$\overline{\mathrm{x}}=$ Rata - rata

Hasil analisis data penelitian menunjukkan rata-rata persentase pemahaman peserta didik pada konsep gerak lurus dapat dilihat pada Gambar 1.

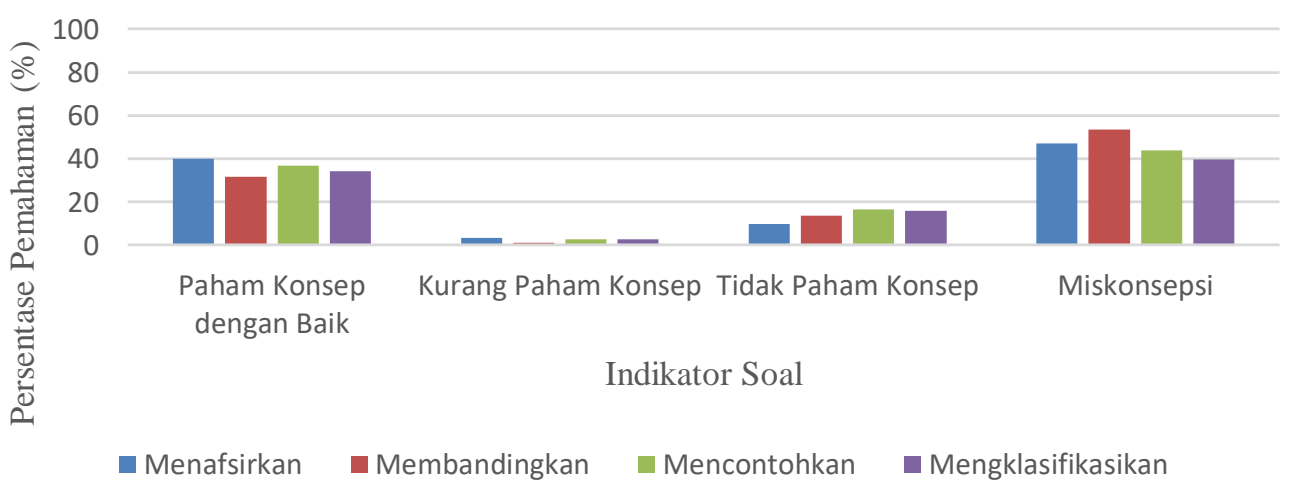

Gambar 1. Diagram rata-rata persentase kategori pemahaman peserta didik pada konsep gerak lurus 
Pada konsep gaya rata-rata persentase kategori pemahaman konsep peserta didik dapat dilihat pada Gambar 2.

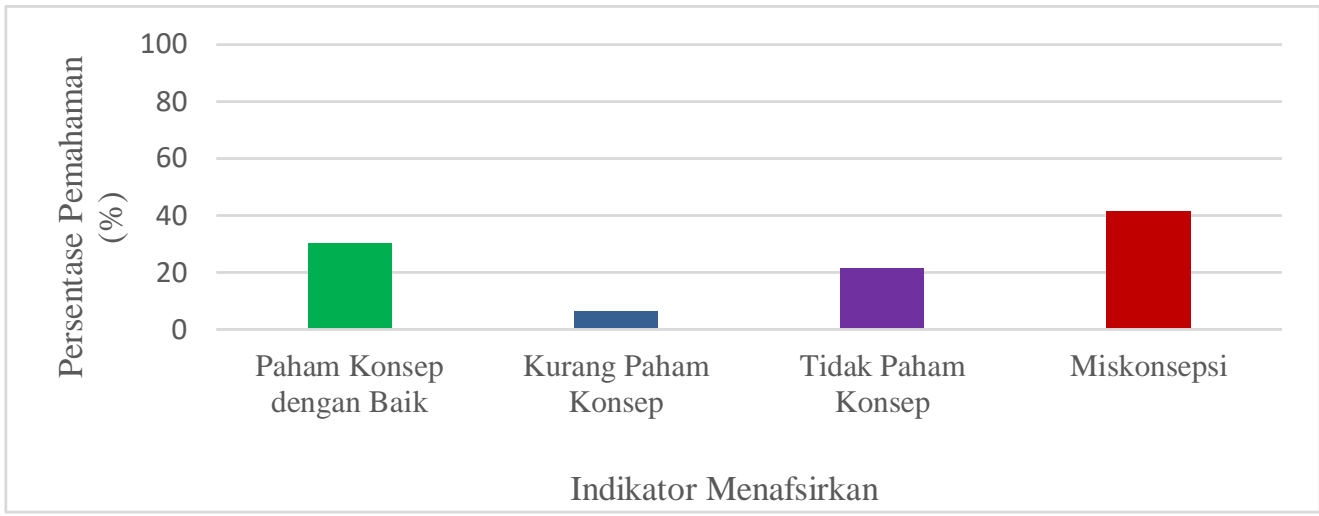

Gambar 2. Diagram rata-rata persentase kategori pemahaman peserta didik pada konsep gaya

Untuk Konsep Hukum Newton rata-rata persentase pemahaman konsep peserta didik untuk semua kategori pemahaman dapat dilihat pada Gambar 3.

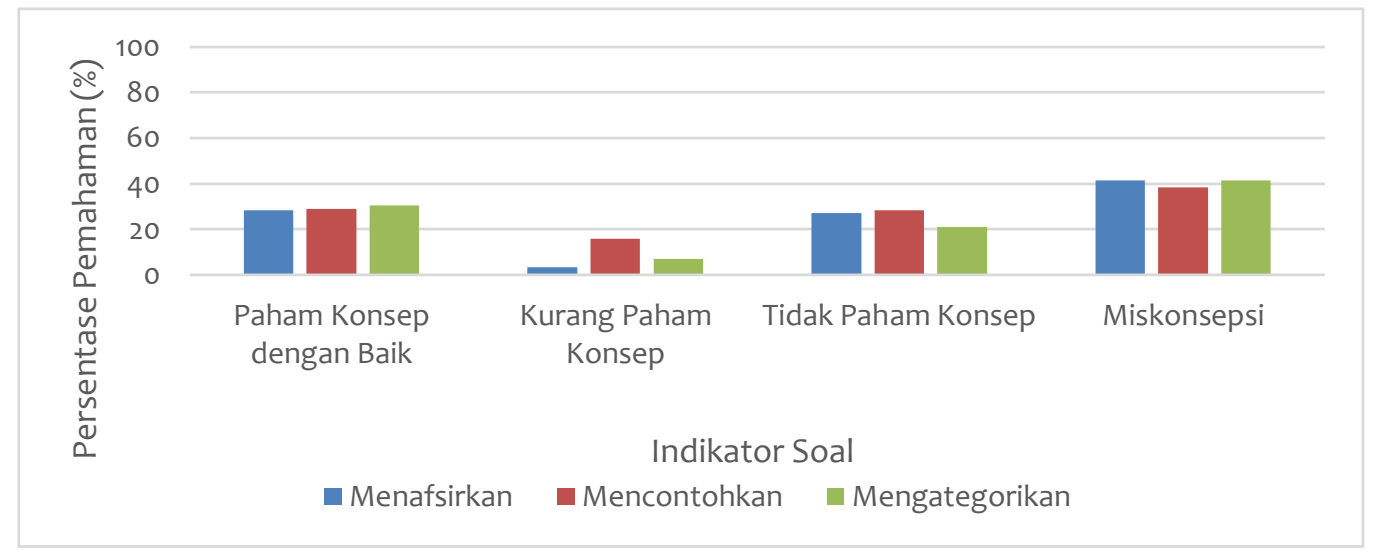

Gambar 3. Diagram rata-rata persentase kategori pemahaman peserta didik pada konsep Hukum Newton

\section{Pembahasan}

a. Deskripsi Miskonsepsi Peserta Didik pada Konsep Gerak Lurus

1) Indikator menafsirkan

Pada indikator menafsirkan peserta didik diminta untuk menafsirkan konsep gerak. Peserta didik yang mengalami miskonsepsi sebesar sebanyak $47,1 \%$. Pada soal tersebut teridentifikasi kesalahan peserta didik terbanyak pada bagian jawaban tingkat pertama. Peserta didik sebelum menjawab harus memahami konsep gerak. Peserta didik yang mengalami miskonsepsi menjawab hanya dengan memahami bahwa bumi bergerak mengelilingi matahari tanpa memperhatikan titik acuan yang telah ditentukan pada soal. Sedangkan konsep gerak menyebutkan bahwa benda dikatakan bergerak apabila terjadi perubahan posisi benda terhadap titik acuan (tempat pengamat). Kesalahan peserta didik dalam memahami konsep gerak karena hanya memahami bahwa gerak adalah perubahan posisi benda, tanpa memperhatikan kedudukan dimana pengamat (titik acuan) berada. 


\section{2) Indikator membandingkan}

Pada indikator membandingkan peserta didik diminta untuk membedakan antara jarak dan perpindahan. Peserta didik yang mengalami miskonsepsi sebesar sebanyak $57,5 \%$. Pada soal tersebut teridentifikasi kesalahan peserta didik terbanyak pada bagian jawaban tingkat satu. Pada soal ini kategori miskonsepsi yang terjadi pada peserta didik yaitu menjawab salah pada jawaban tingkat satu dan benar pada jawaban tingkat dua. Peserta didik secara teori mengetahui konsep perpindahan namun dibuktikan dengan banyaknya peserta didik yang menjawab benar pada jawaban alasan (jawaban tingkat dua). Tetapi pada jawaban tingkat satu peserta didik salah dalam memberikan jawaban yang benar.

Jawaban alasan yang diberikan peserta didik yaitu perpindahan merupakan selisih kedudukan akhir dengan kedudukan awal dari suatu benda, sedangkan pada jawaban tingkat satu peserta didik memberikan jawaban salah karena menganggap selisih angka yang tertera pada speedometer merupakan perpindahan yang dialami, sedangkan jawaban yang benar adalah benda tidak mengalami perpindahan yang dapat dilihat dari selisih anatara kedudukan awal dan akhir yang tertera pada soal. Ini bermakna bahwa peserta didik tidak terlalu memahami konsep jarak dan perpindahan dengan baik. Mereka hanya mengandalkan hafalan mengenai konsep tersebut tanpa memperhatikan dan memahami makna dari kata kedudukan awal dan kedudukan akhir suatu benda. Peserta didik kurang memahami maksud dar pertanyaan yang diberikan dan tidak memahami dengan baik konsep jarak dan perpindahan yang sesuai dengan apa yang telah diajarkan dan dikemukakan oleh para ahli fisika. Kesalahan konsep yang dialami peserta didik ini karena tidak dapat membedakan antara jarak dan perpindahan yang dialami oleh benda.

\section{3) Indikator mencontohkan}

Pada indikator mencontohkan peserta didik diminta untuk menentukan contoh dari gerak lurus berubah beraturan. Peserta didik yang mengalami miskonsepsi sebesar sebanyak 45,5\%. Pada soal tersebut teridentifikasi kesalahan peserta didik terbanyak pada bagian jawaban tingkat dua (alasan). Pada soal ini kategori miskonsepsi yang terjadi pada peserta didik yaitu menjawab benar pada jawaban tingkat satu dan salah pada jawaban tingkat dua. Pada butir soal ini peserta didik mampu menentukan contoh dari gerak lurus berubah beraturan dibutikan dengan banyaknya peserta didik yang menjawab benar pada butir soal ini. Namun untuk jawban tingkat dua (alasan) peserta didik menjawab salah.

Peserta didik mengalami miskonsepsi karena peserta didik tidak memberikan alasan yang benar untuk jawaban pada butir soal ini. Berasarkan pada soal tersebut contoh peristiwa yang di kategorikan sebagai benda yang bergarak lurus berubah beraturan dipercepat adalah benda jatuh yang kecepatan bendanya semakin kebawah semakin bertambah. Mereka tidak memahami dengan baik konsep gerak lurus berubah beraturan dipercepat karena eserta didik menganngap bahwa bola yang menggelinding diatas pasir merupakan contoh dari gerak lurus berubah beraturan dipercepat.

\section{4) Indikator mengklasifikasi}

Pada indikator mengklasifikasi peserta didik diminta untuk menentukan contoh dari gerak lurus berubah beraturan. Peserta didik yang mengalami miskonsepsi sebesar 39,7\%. Pada soal tersebut teridentifikasi kesalahan jawaban peserta didik terbanyak terdapat pada kedua tingkatan soal. Pada soal ini kategori miskonsepsi yang terjadi pada peserta didik yaitu menjawab salah pada jawaban tingkat satu dan salah pada jawaban tingkat dua namun tetap yakin dengan jawaban yang diberikan. Pada butir soal ini peserta didik tidak mampu mengklasifikan konsep kelajuan dan kecepatan di butikan dengan banyaknya peserta didik yang menjawab salah pada jawaban tingkat satu dan tingkat dua (alasan) pada butir soal ini. 
Peserta didik mengalami miskonsepsi karena peserta didik tidak memberikan jawaban dan alasan yang benar. Berasarkan pada soal tersebut pernyataan yang diberikan untuk mengetahui konsep kelajuan dan kecepatan yang mana konsep kecepatan diartikan sebagai besaran yang memiliki nilai satuan dana rah. Sedangkan konsep kelajuan merupakan besaran yang hanya memiliki nilai dan satuan.

\section{b. Deskripsi Miskonsepsi Peserta Didik pada Konsep Gaya}

Pada sub konsep gaya indikator pemahaman menafsirkan peserta didik diminta untuk menafsirkan konsp gaya. Peserta didik yang mengalami miskonsepsi sebesar sebanyak 41,7\%. Pada soal tersebut teridentifikasi kesalahan peserta didik terbanyak pada bagian jawaban tingkat satu (pilihan jawaban). Pada soal ini kategori miskonsepsi yang terjadi pada peserta didik yaitu menjawab salah pada jawaban tingkat satu dan benar pada jawaban tingkat dua. Pada butir soal ini peserta didik menjawab salah tentang konsep gaya di butikan dengan banyaknya peserta didik yang menjawab salah pada soal tingkat satu. Namun untuk jawaban tingkat dua (alasan) peserta didik menjawab benar.

Peserta didik mengalami miskonsepsi karena peserta didik memberikan jawaban yang salah dan alasan yang benar pada butir soal ini. Berdasarkan pada soal tersebut pernyataan yang benar menganai tafsiran konsep gaya yaitu tarikan atau dorongan terhadap suatu benda yang menyebabkan perubahan kecepatan dan bentuk benda. Sementara jawaban yang diberkan peserta didik gaya merupakan tarikan atau dorongan yang dapat menyebabkan perubahan ukuran dan bentuk benda hal ini bermakna bahwa kesalahan konsep yang dialami peserta didik karena mengandalkan hafalan tanpa memahami dan menelaah dengan baik pertanyaan yang diberikan.

\section{c. Deskripsi Miskonsepsi Peserta Didik Sub Konsep Hukum Newton}

\section{1) Indikator menafsirkan}

Pada indikator mengklasifikasi peserta didik diminta untuk menentukan contoh dari gerak lurus berubah beraturan. Peserta didik yang mengalami miskonsepsi sebesar sebanyak 41,5\%. Pada soal tersebut teridentifikasi kesalahan jawaban peserta didik terbanyak terdapat pada kedua tingkatan soal. Pada soal ini kategori miskonsepsi yang terjadi pada peserta didik yaitu menjawab salah pada jawaban tingkat satu dan salah pada jawaban tingkat dua namun tetap yakin dengan jawaban yang diberikan. Pada butir soal ini peserta didik tidak mampu memahami kosnsep Hukum II Newton yang disajiakn dengan contoh di butikan dengan banyaknya peserta didik yang menjawab salah pada jawaban tingkat satu dan tingkat dua (alasan) pada butir soal ini.

Peserta didik mengalami miskonsepsi karena peserta didik tidak memberikan jawaban dan alasan yang benar. Berasarkan pada soal tersebut pernyataan yang diberikan untuk mengetahui konsep Hukum Newton II yang mana Hukum II Newton menyatakan bahawa percepatan suatu benda berbanding lurus dengan gaya yang bekerja dan berbanding terbalik dengan massanya.

\section{2) Indikator mencontohkan}

Pada indikator mengklasifikasi peserta didik diminta untuk menentukan contoh dari penerapan Huukum Newton III dalam kegiatan sehari-hari. Peserta didik yang mengalami miskonsepsi sebesar sebanyak 49,6\%. Pada soal tersebut teridentifikasi kesalahan jawaban peserta didik terbanyak terdapat pada kedua tingkatan soal. Pada soal ini kategori miskonsepsi yang terjadi pada peserta didik yaitu menjawab salah pada jawaban tingkat satu dan salah pada jawaban tingkat dua namun tetap yakin dengan jawaban yang diberikan. Pada butir soal ini peserta didik tidak mampu menentukan contoh Hukum III Newton yang disajiakn dengan beberapa contoh kegiatan. Kesalahan konsep peserta didik pada butir soal ini dibutikan dengan banyaknya peserta didik yang menjawab salah pada jawaban tingkat satu dan tingkat dua (alasan). 
Peserta didik mengalami miskonsepsi karena peserta didik tidak memberikan jawaban dan alasan yang benar. Berasarkan pada soal tersebut pernyataan yang diberikan untuk menentkan contoh Hukum III Newton yang mana Hukum III Newton Jika sebuah benda memberikan gaya pada benda lain, maka benda yang terkena gaya akan memberikan gaya yang besarnya sama dengan gaya dari benda pertama tetapi arahnya berlawanan.

\section{3) Indikator mengategorikan}

Pada indikator mengklasifikasi ini peserta didik diminta untuk menentukan contoh dari gerak lurus berubah beraturan. Peserta didik yang mengalami miskonsepsi sebanyak 46,1\%. Pada soal tersebut teridentifikasi kesalahan peserta didik terbanyak pada bagian jawaban dua (pilihan alasn). Pada soal ini kategori miskonsepsi yang terjadi pada peserta didik yaitu menjawab benar pada jawaban tingkat satu dan salah pada jawaban tingkat dua. Pada butir soal ini peserta didik menjawab salah dalam mengategorikan pasangan aksi reaksi yang benar berdasarkan hukum III Newton tentang konsep gaya di butikan dengan banyaknya peserta didik yang menjawab salah pada soal tingkat dua. Namun untuk jawaban tingkat satu peserta didik menjawab benar.

Peserta didik mengalami miskonsepsi karena peserta didik memberikan jawaban yang benar dan alasan yang salah. Berdasarkan soal tersebut, pada saat burung terbang di udara besar gaya aksi reaksi yang bekerja antara burung dan udara adalah sama karena gaya yang dimiliki burung melebihi besar gaya gesekan udara sehingga burung dapat maju ke depan. Sementara alasan jawaban yang diberkan peserta didik menganggap pula bahwa gaya gesekan udara dengn gaya yang dimilki burung saat terbang adalah sama.

Berdasarkan data hasil penelitian menunjukkan bahwa two-tier test mampu mengidentifikasi pemahaman konsep peserta didik melalui pembagian kategori tingkat pemahaman peserta didik (Tabel 2). Two tier test dibandingkan dengan pilihan ganda tradisional lebih efektif dalam menentukan konsep alternatif peserta didik (Treagust, 2006). Hasil penelitian ini menunjukkan bahwa two tier tes dapat mengindentifikasi miskonsepsi yang tejadi pada peserta didik untuk setiap konsep. Persentase miskonsepsi pada konsep gerak lurus pada indikator membandingkan dengan pesertase 57,5\%. Untuk konsep gaya pada indikator menafsirkan persentase miskonsepsi peserta didik sebesar $41.7 \%$. Sedangkan untuk konsep Hukum Newton pada indikator mencontohkan memiliki persentase miskonsepsi yaitu 49,6\%.

\section{KESIMPULAN}

Berdasarkan hasil analisis data dan pembahasan maka dapat disimpulkan bahwa miskonsepsi peserta didik yang teridentifikasi terjadi di setiap konsep pada materi gerak pada benda. Tingkat miskonsepsi peserta didik pada setiap konsep yaitu pada konsep gerak lurus pada indikator membandingkan dengan pesertase $57,5 \%$. Untuk konsep gaya pada indikator menafsirkan persentase miskonsepsi peserta didik sebesar $41.7 \%$. Sedangkan untuk konsep Hukum Newton pada indikator mencontohkan memiliki persentase miskonsepsi terendah yaitu $49,6 \%$.

\section{DAFTAR PUSTAKA}

Arslan, H. O., Cigdemoglu, C., \& Moseley, C. (2012). A Three-Tier Diagnostic Test to Assess PreService Teachers' Misconseption about Global Warming, GreenHouse Effect, Ozone Layer Depletion, and Acid Rain. International Journal of Science Education.

Hasan, S. B. (1999). misconceptions and the certainty of responce index. physic education.

Mustaqim, T. A. (2014). Identifikasi Miskonsepsi Siswa dengan Menggunakan Metode Certainty of Response Index (CRI) pada Konsep Fotosintesis dan Respirasi Tumbuhan. Edusains. 
Ormrod, J. E. (2009). Psikologi Pendidikan Membantu Siswa Tumbuh dan Berkembang. Jakarta: Erlangga.

Siswana, R. A. (2017). Identifikasi Miskonsepsi Materi Fotosintesis pada Siswa Kelas IX SMPN 7 Padang Menggunakan Tes Diagnostik Two Tier Multiple Choice. Jurnal Biosains.

Suparno, P. (2005). Miskonsepsi dan Perubahan dalam Konsep Fisika. jakarta: Grasindo.

Tuysuz, C. (2009). Development of Two-tier Diagnostic Instrument and Asses students Understanding in Chemistry. Academic Journal of Scientific Research and Essay, 4 (6).

Wisudawati, A. W. (2014). Metodologi Pembelajaran IPA. Jakarta: Sawo Raya.

Wiyono, F. M., Sugiyanto, dan Erni Y. (2016). Identifikasi Hasil Analisis Miskonsepsi Gerak Menggunakan Instrumen Diagnostik Three Tier pada Siswa SMP. Jurnal Pendidikan Fisika dan Aplikasinya, 6 (2).

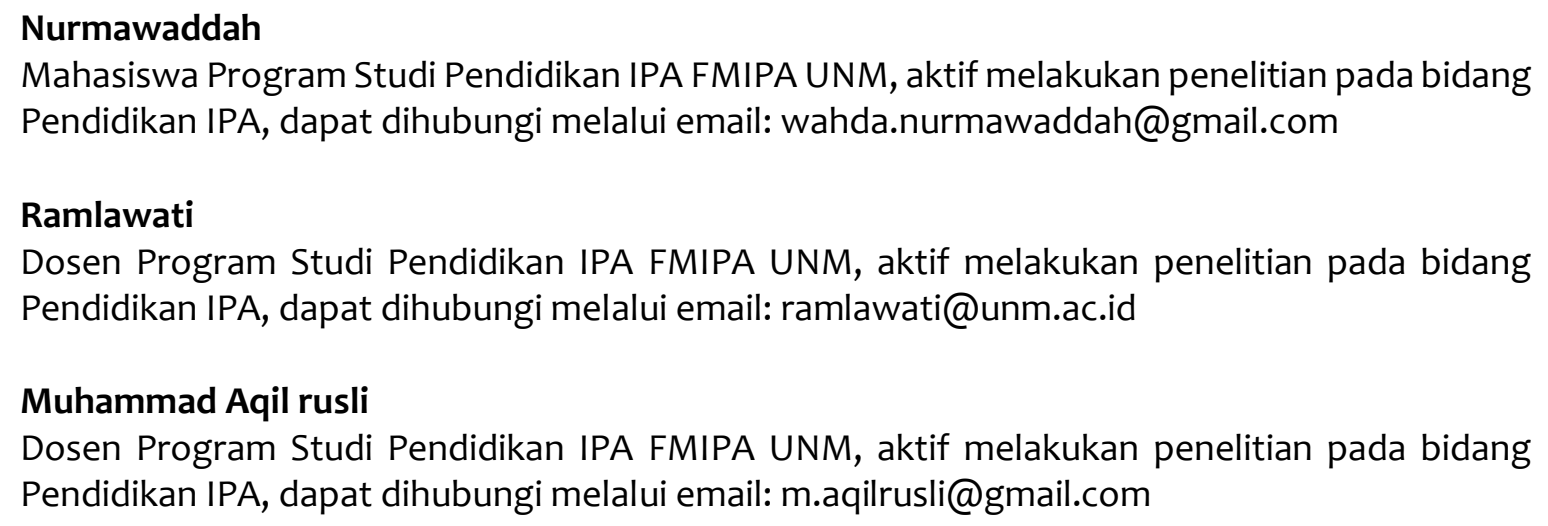

\section{Muhammad Aqil rusli}

Dosen Program Studi Pendidikan IPA FMIPA UNM, aktif melakukan penelitian pada bidang Pendidikan IPA, dapat dihubungi melalui email: m.aqilrusli@gmail.com 